\title{
The Gramscian Intervention in the Theoretical and Political Production of the Latin American Left ${ }^{1}$
}

\author{
by Raúl Burgos ${ }^{2}$ \\ Translated by Carlos Pérez ${ }^{3}$
}

Que le dijo el movimiento comunista internacional a Gramsci No tengo edad,
no tengo edaaaad para amarte... -

Numerous studies exist on the dissemination of Antonio Gramsci's work in Latin America.That the subject merited an international conference organized by the Instituto Gramsci (Gramsci Institute) in Italy titled "Political Transformations in Latin America: Gramsci's Presence in Latin America Culture" 1 in itself demonstrates the importance of his ideas in the region. I would like to advance some observations concerning this process.

First, chronology: the history of the relationship between Latin America and Gramsci's thought can be divided into two distinct periods, one extending from the 1950s to 1975 and the other from 1975 to the present.During the first period, Argentina and Brazil were the principal centers for the publication of Gramsci's writings. The Argentine editions of the Editorial Lautaro, which was associated with the Partido Comunista de la Argentina (Communist party of Argentina-PCA), achieved the first continental diffusion of Gramsci's work, ${ }^{2}$ and after 1963 the editions of the Pasado y Presente group appeared, along with the Brazilian editions of Civilização Brasileira. ${ }^{3}$ During the second period, according to José Aricó (1988: 12, using an expression

\footnotetext{
${ }^{1}$ This article was presented at the annual congress of the Latin American Studies Association in Guadalajara, Mexico, April 17-19, 1997, and summarizes the main contents of a study conducted between 1991 and 1995 under the title "As peripécias de Gramsci entre Gulliver e Pequeno Polegar." The historical analysis therefore ends with 1997; a few notes have been added for readers' information.

${ }^{2}$ Raúl Burgos is a professor of social sciences at the State University of Campinas, São Paulo, Brazil.

${ }^{3}$ Carlos Pérez is an assistant professor of Chicano and Latin American Studies at California State University, Fresno.
} 
coined by Marco Aurélio Nogueira for Brazil), Gramsci's ideas “erupted like a volcano" in Latin America.

Secondly, a political-theoretical observation: during the first period the spread of Gramscian thought did not conflict with the classical paradigm on revolution that had emerged from the Russian Revolution. In the Argentine case, from 1950 to 1963 Gramsci, linked with and restricted to the PCA's cultural sectors, was read primarily as a cultural theoretician. During the second phase of this period, in the hands of members expelled from the PCA, his work was utilized by political currents critical of its political and theoretical positions but still in the Leninist tradition.Aricó $(1988: 62-63,75)$ explained:

The journal [Pasado y Presente], whose first series ended in September 1965, attempted to recuperate Marxism's hegemonic capacity by subjecting it to the demands of the present. From this concern, although its contributions might not have expressed it directly, we questioned so-called Marxism-Leninism as a theoretical and political heritage for the foundation of a transformational culture.Lenin was, for us, the practical demonstration of the strength of a particular method and not a set of abstract and immutable principles; his philosophy was not to be sought where one thought one might find it but instead could be found in his practical action and his reflections on it—not in Materialism and EmpirioCriticism but in the April Theses. ...

We were a rare mix of followers of Guevara and Togliatti. If this unlikely combination was ever possible, we expressed it.

Subsequently, the group added to its theorizing "the Leninist and Gramscian matrix" that constituted the theoretical foundations for its reflections. "Gramsci did not free us from Lenin," Aricó declared, summarizing what I consider a fairly general characteristic of the New Left of that period, "but simply permitted us to acquire a much more complex and open idea of his thought" (Aricó, 1988: 79).

For his part, Juan Carlos Portantiero (1991: 8) commented on the same point:

It was not only about Gramsci. We concocted a sort of cocktail in which Gramsci coexisted with Guevara and the Chinese Revolution. In that combination we saw possibilities for an articulation with a historicist and voluntarist discourse in contradistinction to one that appeared to us speculative and scientistic. Any one of those three openings (culturalism, Gramsci, or Guevara) allowed us to think of things in this way, although we mainly utilized Gramsci because of his analysis of culture and the subaltern classes.

Thirdly, an observation on the area of diffusion: in the first period, Gramsci did not achieve prominence in the university. In the 1950s his 
influence was limited to small circles. During the 1960s, designated by Aricó as the "Cuban years," debates in Latin American universities centered on the questions raised by the Cuban Revolution. These issues expressed a state of mind and a spiritual predisposition toward a type of reading in which Gramsci entered tangentially as a part of a renovating movement within Marxism but without any particular relevance. It was only at the end of this first period that Gramsci began to play a major role in academia. During the second period, in contrast, he was thoroughly ensconced within the university, which became a privileged space for discussion and dissemination of his work.4 Arnaldo Córdova (1988: 98), referring to Gramsci's reception in the Mexican university environment in the 1960s, indicated a shift from the previous direction of diffusion:

Something positive occurred outside of the militant left when Gramsci entered the academic environment. Young Marxist professors without any political affiliations, many of whom had studied in Europe, including in Italy, brought along with the recently discovered works of the young Marx a new view of Marxism in which it was common and necessary to reference Gramsci.....Now many people were introduced to Gramsci in the Italian, since the Argentine translations of his works were out of print and not circulating in the mid-1960s.

Córdova recognized that "in spite of everything, the number of those familiar with Gramsci continued to be extremely limited." At the same time, he pointed out that Gramsci became generally known through the works of Althusser, with all of the problems that this mediation entailed. It is valid to conclude from Córdova's text that the introduction of Gramsci to the universities of Latin America was diffuse, "molecular," in form.

Although Mexico's internal political structure was conflictive, its foreign policy provided a generous haven for exiles with different political tendencies in the mid-1970s.In the second half of the 1970s many Latin American leftist intellectuals and militants escaping the military dictatorships of the period found in Mexico a welcome refuge, making the country the nerve center for Latin American political life. In a South America submerged in bloody military dictatorships, with political democracy reigning in only a few countries, and a Central America aflame with revolutionary movements, Mexico (primarily, although it was not alone: Venezuela, Cuba, and Costa Rica played a similar role, although with less influence) became a sounding board and a privileged arena for observation, study, and discussion, in its universities and research institutions, of the processes under way in Latin American societies. At the same time, it became an important place for the publication of works related to socialist culture and, especially, Marxism. This "cultural soup" became a marvelous setting for 
an extensive reflective exercise by the Latin American left on the reasons for the failure of the transformational projects confronted not only by the old left but also by the so-called revolutionary left that emerged in the 1960s.

It is worth emphasizing certain "institutional" characteristics of the discussion and spread of leftist ideas under these circumstances. Numerous important scholarly conferences played an influential role. The proceedings of the Mérida (Yucatán) Conference were published by Siglo XXI as Las clases sociales en América Latina in 1973; the Oaxaca Seminar resulted in the 1977 publication, again by Siglo XXI, of Clases sociales y crisis politica en América Latina; the October 1978 Puebla Seminar "The Transitional State in Latin America" was published by the Universidad Autónoma de Puebla in 1980 as Movimientos populares y alternativas de poder en Latinoamérica; the Culiacán Conference of 1980 dealt with the work of José Carlos Mariátegui; and the proceedings of the 1980 Morelia (Michoacán) Seminar, devoted to the discussion of the methodological and political functionality of the concept of hegemony, were published as Hegemonia $y$ alternativas políticas en América Latina by Siglo XXI in 1985.In particular, the latter conference was conceived within the problematic intersection of practical politics and theory, so it was not accidental that the Gramscian conceptualization of hegemony provided the focus. José Aricó $(1985: 12,11)$ reflected five years later in the preface to the book that emerged from this seminar:

The seminar attempted to bridge the gap between the analysis of reality and the theoretical and political propositions regarding its transformation. Without forgetting that the focus of a social science seminar is the discussion of political theory, we sought to approximate a politics capable of struggling for a level of mediation with reality where the rigid boundaries between the "academic" and the "political" become blurred. . .

The seminar ...did not attempt to analyze the historical path the dominant classes undertook to impose their hegemony in Latin America or how they maintain it. Instead, we discussed and studied the theoretical and practical reconstruction and processes necessary for constructing a proletarian or popular hegemony capable of initiating a radical transformation in keeping with the democratic aspirations of the continent's working classes. It was precisely this perspective of the popular classes that we sought to highlight.

The editor of the book, Julio Labastida (1985: 9-10), the director of the Institute for Social Research of the National Autonomous University of Mexico during that period, stated in his introduction: 
Confronted in the field of political thought with the absence of a theory capable of uniting democratic and socialist moments, the Marxist currents have insisted on the classical idea that a class alliance led by the proletariat could ignite a mass movement of social protest, led by a particular political organization capable of generating a social crisis leading to the transformation of the existing political order. According to this idea, the primary goal of the popular classes is expressed in a strategy called the "accumulation of forces" that pre- pares the stage for the taking of political power. As long as this accumulation of forces is considered solely instrumentally as a tool for unity and not as the conscious expression of a strategic basis for a theory of transition, it cannot serve as a vehicle for uniting the heterogeneous popular classes in an all-encompassing social project.

Not being the result of true and effective political and social unification of the masses, past political processes led to a transitory conquest of power. Therefore, they were not prepared to perform the difficult tasks that a complete political, social, and economic transformation of a country requires. Unable to achieve the full consensus of the popular classes, they quickly turned to authoritarian solutions. The fact that in their analysis of these experiences the socialist left frequently blames "external" factors for the failure of the process reveals the limitations of a strategic hypothesis. Finally, to the extreme voluntarism of the theory corresponds a practice that dichotomizes democratic and socialist proposals.

In this respect, the seminar's objective was to consider the possibilities of establishing an integrative analytical field that would not only disarticulate theory and reality but also create a conflict between them. This would assume a critical reconsideration of the analytical categories utilized up to the present.

The seminar's objectives, synthesized by Aricó and Labastida, demonstrate the theoretical-political challenge to many of the period's intellectuals.

Two accomplishments of left intellectuals during this period are outstanding: the discovery of José Carlos Mariátegui's search for the construction of a nondogmatic Marxism with Latin American roots and an indigenous socialist project and a rereading of Gramsci's works through new formulas. As an integrative element in the great flood of antidogmatic critiques, Gramscian thought in Latin America produced two principal models: the "nationalpopular" culturalist model and the worker's "council" model. Both models attempted to understand the problems encountered by earlier transformational projects when they tried to insert themselves into the "exotic" Latin American reality. Concerning the nature of the reading that Gramsci received in Brazil at the end of the 1960s, Carlos Nelson Coutinho (1989: 59) wrote:

We did not embrace the Gramsci who was the critical theoretician of the "allencompassing" state and the socialist revolution in the "West" or the one who researched the "nonclassical" forms of the transition to capitalist modernity 
(the problematic of the "passive revolution").Instead, we focused on the "philosopher of praxis" who proposed a humanistic and historicist reading of Marxism that differed from the predominant Soviet vulgate. Therefore, it is not coincidental that during the initial introduction of Gramsci into Brazil he appeared next to Lukács and the Sartre of the Critique of Dialectical Reason. The three were introduced as privileged instruments in the antidogmatic struggle fundamentally centered on the battlefield of philosophy, aesthetics, and the sociology of culture.

The new perspective radically transformed the foundation for thought by centering on Gramsci as the "theoretician of hegemony." This theoretical inflection became the key factor in future innovations by changing the logic of thinking about social transformation in Latin America. The previous model for discussing the work of Gramsci and other advocates of so-called Western Marxism was based on the logic of the assault on power, a theory of the transformation process that finds its most relevant theoretician in Lenin. The new perspective offered another way of thinking about the radical trans- formation of society: one goes from the logic of the assault on power to the logic of the construction of new centers of power within the present society - the logic of the construction of hegemony.

The Leninist theory of revolution, the old logic, added to the traditional concepts of historical materialism a series of elements taken primarily from the experience of the Russian Revolution:

1. A theory of the conditions for revolution that implied a correlation between "objective" and "subjective" conditions. The objective conditions focused on the development of a sufficient material base and on the working class as the principal motor of the socialist revolution. The treatment of the subjective conditions had two principal trajectories: a "theory of the major social forces" of the revolution and a "theory of the vanguard" or "revolutionary party." The theory of the major social forces had two central concepts: the primary role of the working class and its alliance with other nonantagonistic classes, primarily the poor peasants and, secondly, the urban petty bourgeoisie. The theory of the vanguard rested on the idea that the most conscious elite of the revolutionary worker's movement had to direct and organize the revolutionary process, with the whole movement submitting to the "revolutionary general staff" organized in the party. The basic organizational principle of this general staff was that of democratic centralism, considered as a principle that reflected the dialectical nexus between knowledge and the transformation of the world.

2. A theory of the state that conceived of it in a restricted instrumental sense as a bureaucratic-military apparatus to be taken and destroyed. From its ashes a new state would be constituted. 
3. A theory of the crisis of the state, much more complex than the theory of the state, with generalized social disorganization as its central theme. Lenin synthesized the revolutionary situation as the stage in which "those above can't and those below don't want to" maintain the prevailing state of things.

4. Finally, a theory of revolution seen strictly as the "taking of political power for the subsequent transformation of the socioeconomic structure," the first moment being explosive and the second moment, dependent on the first temporally and logically, taking longer. The first moment would be relatively easy to achieve in less developed capitalist societies and more difficult in developed ones, the second more complicated in underdeveloped societies and relatively easy in advanced capitalist societies once "socialism" is considered, in its first stage, as a "change of hands" in the administration of social wealth. The "dictatorship of the proletariat" was the basic concept in this theory of revolution, to the point that it was more precisely a theory of the conditions for the realization of the dictatorship of the proletariat.

In this model, the socialist character of the revolutionary act was given by two principal factors: the "proletarian" character of the central subject of the changes and the transfer of the key means of production to the state and, with this act, formally, to society. This second factor contains a series of reductions: (1) The totality of social relations is reduced to what is considered their essence, the relations of production. (2) The relations of production, in turn, are reduced to their essence, property relations. (3) The social ownership of the means of production is reduced to state administration according to the formula "property of the state = social property."

Therefore, for this model the socialist character of the revolution is based on an action whereby the revolutionary movement's political vanguard seizes political power (the state's bureaucratic-military apparatus) and from that vantage point produces the socialist transformation of the economic base; the primary action is the socialization (state ownership) of the principal means of production. In this model there is no socialist revolution without this action, and without a political revolution (seizing, assaulting power) this action is impossible. Without the transfer of economic power to the state, any type of socialist transition is considered reformism, a more or less democratizing form of capitalism.

This, in broad strokes, was the model that had to be criticized. To accomplish this task, several of Gramsci's concepts were used as basic theoretical instruments either for the construction of a new logic concerning social transformation or as a means for engaging the model in a fruitful dialogue in order to strengthen it. The new logic went roughly as follows:

1. Revolution is not simply a single explosive act but a process in which new power relationships are constructed along with new levels of culture 
and organization of the society, in keeping with a strategy that can be conceived in terms of the Gramscian metaphor of the "war of positions." The polemical outlines of this idea are found not only in the old left paradigm but also in the existing social democratic model. This conceptualization not only opposes the idea of a specific and explosive act with the idea of "process" but also goes against the social democratic paradigm, which puts forward an infinite evolution whose asymptotic limit never ceases to be capitalism, by proposing the necessity of successive and continuous anticapitalist ruptures. At the same time, it develops a critique of the economicism associated with the old position, since the ruptures pertain not only to the economic order but to the multiple interstices of the social process. For example, the First Congress of the Partido dos Trabalhadores (Workers' party-PT) arrived at the following synthesis (PT, 1991: 52):

If we do not see the taking of political power as an "assault on the state," we also do not believe that socialism will occur through the continuous and linear progress of the socialist forces and their hegemony within society but will require intense confrontations and struggles. We reaffirm, therefore, that the cultural, political, and economic transformations that Brazil requires assume a social revolution.

The conquest of power is a moment of the struggle for socialism, but it does not in itself guarantee construction. The conquest of power may signify the will of the majority, but it is not synonymous with a political hegemony based on a global project, much less with an ideological or cultural one. Its consolidation will depend on the democratic exercise of power as a means of understanding the numerous ideological, political, and material contradictions remaining, even among social revolutionaries.

2. Therefore, the idea of seizing or assaulting power is displaced by that of the creation of new relations of power for the conquest of hegemony. This task conceives political democracy as a necessary and enduring terrain for the construction of the strategic transformational project. The movements emerging from civil society will have predominance over the actions of the state in the projection and construction of a new society. The foundation for this idea approximates the Gramscian notion of the "reabsorption of political society by civil society." Aricó (1985: 14) expressed the question as follows:

What makes the Gramscian concept of hegemony a break with preceding Marxist theorizing is that it is presented as transcending the Leninist idea of class alliances, which privileged the constitution of social subjects by absorbing and displacing the positions that Gramsci identified as "economiccorporate," therefore making it incapable of becoming a "state." Understanding it in this manner, hegemony is a constitutive process in which the social agents themselves are responsible for developing a state or, in other words, a hege- 
monic force.In this way, by grasping such Gramscian categories as the "formation of a national-popular will" and "intellectual and moral reform" and all that they imply outside of the particular concrete historical terrain from which they emerged, the configuration of hegemony develops as a movement that above all affects the social construction of reality and concludes by reconstructing in a completely new way the social subjects themselves.

3. An idea of socialism is constructed that is conceived as a "synonym for the radicalization of democracy" (PT, 1991: 32), which should be not only political but also, necessarily, social and economic. It should also be thought of as a space for the establishment and conquest of new rights for all citizens. The accent is on the self-organization and self-management of the community, approaching the Gramscian idea of a [self-]regulated society. On this point, Aricó (1988: 116-117) wrote:

The objective of maintaining the unity of democracy and socialism assumes in political practice the struggle for constructing a political and social order in which the permanent conflictivity of society finds forms of resolution that favor its democratization without making it ungovernable. The immediate task, then, is nothing other than the development of alternative forms of culture, organization, and struggle that call institutionalized hierarchy and norms into question, therefore contributing to the creation of popular subjects imbued with an autonomous will with which to participate fully in public life.

4. The restricted notion of the social subject of the transformation (the working class as the driving force) is replaced by a new idea of that subject as a heterogeneous and multiple "social bloc." Providing channels for the diverse demands made by the various classes and subaltern sectors energizes the transformational process. The First Congress of the PT expressed this as follows (PT, 1991: 41):

The party should rethink its actions within society through an understanding of the various forms of oppression it contains. This oppression cannot be summed up as the contradiction between capital and labor but must be seen as extending to discriminatory and exclusionary cultural, political, social, and economic practices expressed in terms of class, race, and gender. These characteristics of the process of domination are not only part of the expression of political power but also permeate society and are responsible for the transformation of social majorities into political minorities.

Therefore, this course of action should lead to the "constitution of a political and social bloc united in a common struggle and in the alliances necessary for the construction of a democratic and popular alternative" (PT, 1991: 36). 
5. The Leninist conception of the party and its relationship to social movements, the classical left position "converting it into a horizontal relationship" (Villalobos, 1992: 36), is questioned. The ideas of autonomy, self-management, participatory democracy, and so forth, become the basis for a model of the relationship between the party and social movements. In this new perspective the party is conceived as an instrument for articulating and representing social forces and interests in government bodies but maintains a relationship of equals with social movements, seeking an intellectual and moral direction and not simply instrumental organic management. According to the PT (1991: 57-58),

Our principal concern should be merging the PT as a movement and as an institution. It is a movement with deep roots in Brazilian society and its working class - the social base of our party-expressed as a political, social, and cultural force capable of maintaining a relationship and permanent dialogue with other social movements and political parties. It is a representative mass party that through its dedication, spontaneity, integrity, and creativity will revolutionize society ...a mass party with diverse organizational forms: a party that dialogues and proposes a course of action to the various social sectors that aspire to become the leading hegemonic power.

Aricó's (1988) book is an excellent but incomplete attempt to understand the diffusion of Gramsci's thought in the region. After demonstrating the significance of what he termed the "renewal of the core heritage" of Latin American philosophy, which is a consequence of the fertilization of the work of leftist intellectuals through the application of Gramscian concepts, he lamented that this renewal has not reached the political left (1988: 115116):

It continues to be lamentable that all of the efforts dedicated to renewing the core heritage for ideological and political usage have not had their intended effect. They have remained limited to the intellectual sphere without finding sufficient echo in the political parties of the left. These organizations still question and criticize the historical experiences of socialism and its attempt at organic reconstitution from a party perspective. For this reason, they have raised questions, such as that of political democracy, whose answers are simply ideological, offering a purely instrumental vision of the state and its relationship to society that continues to limit their political practice.

However, during the same period in which Aricó wrote this criticism, suggestive conceptual innovations emerged in many Latin American political organizations, many linked to the influence of Gramscian concepts. Let us examine some of these experiences. 


\section{SPILLOVER FROM INTELLECTUAL CIRCLES AND APPROPRIATION BY THE POLITICAL LEFT}

\section{THE SANDINISTAS}

The Sandinista Revolution and the theoretical constructions concerning social change that it provoked ${ }^{5}$ brought important innovations that were received with relative sympathy or opposition and spread throughout Latin America, leaving traces in the theoretical structure of left politics. These constructions eroded some existing beliefs: (1) Christianity and Marxism, previously conceived as in philosophical opposition, were now seen as being politically complementary.(2) The idea of the social subject of revolution in Latin America now transcended the closed concept of "class" and embraced the idea of the "people." (3) With regard to the political subject of revolution, the idea of the vanguard party became that of a "unified vanguard" or "front" composed of multiple parties. (4) Concerning political democracy, they introduced the idea of pluralism. (5) Concerning the political economy of the revolution, they focused on the question of a mixed economy and a rethinking of the market.

We do not know to what extent or in what way Sandinista ideology influenced the conceptual renewal that took place during the late 1970s. What is clear and, perhaps, decisive is that the idea of an assault on power was dominant in the dynamics of the spread of that ideology. Along with the message of renewal, there were two main ideas: the centrality of armed struggle and the necessity of taking over all political power immediately through a "revolutionary assault." Thus, while the Sandinista Revolution offered original elements, it remained firmly within the revolutionary tradition that began and inspired the Cuban Revolution, and this often helped support the discussions of its most innovative theoretical elements. The purely instrumental view of the state and its relationship with society that the political parties continued to hold was criticized from this position, producing important changes in ideas regarding other problems.

Both the Seventeenth Conference of American Armies in Mar del Plata, Argentina, in 1987 and the right saw the spread of Gramsci's ideas as the era's new ideological danger, pointing to the impact of his work on Latin American protest movements. For example, one of the principal figures involved in the atrocities committed during the 1976-1983 dictatorship in Argentina, General Ramón J. Camps, wrote in La Prensa (May 16, 1987) that "the Gramscian specter haunts contemporary Argentina," adding that executive 
power was being exercised by "a typical representative of home-grown, though a bit primitive, Gramscism." According to this paranoid fantasy, with the coming to power of Raúl Alfonsín as president, the Gramscian intellectuals, the "rearguard of subversion," had taken over the political power structure.

Although exaggerated, these fears were not baseless, for the possible political effects of this "perverse influence" were beginning to be felt. At the beginning of 1989, the Movimiento 19 de Abril (April 19th MovementM-19) and the Colombian government began a dialogue that ended with that group's disarmament and incorporation into the nation's institutional political life. In April of that year, I had the opportunity to interview the political and military chief of that organization, Carlos Pizarro Leongómes, in Santo Domingo, a small town in the central Colombian mountains where the M-19 had established its headquarters and baptized it as the "Citadel of Peace." I was fundamentally interested in finding out more about the type of social change that the M-19 was promoting. Within the framework of that discussion, when we got to the subject of the use of the concept of "class," Pizarro (interview, April 9-10, 1989, Santo Domingo, Colombia) explained:

\begin{abstract}
We speak with notions of "nation" and "people," with Gramscian ideas. We say that the revolutionary sectors have to know how to interpret not just the class interests of a nation's proletariat but the interests of all of society. The problem of this country is not simply a problem of classes. We have to go beyond the concept of class and replace it with one that is more integral. We need to offer alternatives to all of the sectors and operate in a society that seeks consensus and integration rather than authoritarianism and exclusion, even if it is an exclusiveness of the majority. In Colombia, concretely, and I believe in all of Latin America, we need to reformulate the old paradigms that we have inherited from Marxism. We need to discover dynamic alternatives that can satisfy the expectations of the masses and meet the demands of this new cycle in a much more fundamental way.
\end{abstract}

The amazement that these statements created is obvious. A small guerrilla army that called itself "Gramscian" in the violent Colombian geography was certainly an exotic flower.

\title{
THE WORKERS' PARTY
}

Simultaneously with the Sandinista experience, two other events stand out in the Latin American political scene of the late 1970s and early 1980s: the beginning of the civil war in El Salvador, which also marked the birth of the Frente Farabundo Martí de Liberación Nacional (Farabundo Martí Front for 
National Liberation-FMLN) as an insurgent army, and the emergence of the PT in Brazil. These two political parties developed their political projects under totally dissimilar conditions, one engaged in a revolutionary war and the other intervening in its country's political and social life without recourse to arms. Nevertheless, ten years later, at the beginning of the 1990s, they both surprised us with an interesting convergence of strategic perspectives and a fluid political interchange that certainly presented a stimulating theoretical challenge. In the first two years of that decade, the PT, which frightened the nation's elites with the candidacy of Luis Ignácio da Silva (Lula) for president, found itself in a protracted debate concerning its strategic political position, which would be defined in the party's First Congress, held in December 1991 expressly for that purpose. The FMLN, for its part, began the complicated process of negotiating peace accords with the government of El Salvador, with the mediation of the United Nations. It had to redefine all of its strategic concepts, constructing a project that would adapt itself to the new conditions of the social process that were being created. In these circumstances, both parties created strategic projects that utilized the new concepts for thinking about the radical transformation of society, with various of those concepts belonging to the body of work on the Gramscian theme of hegemony.

In the case of the PT, although it would be in the party's mature period that the concept of hegemony would more clearly synthesize the "PT's road towards socialism"- the period beginning with the Fifth Conference in December 1987 and extending to the party's First Congress in December 1991 - the founding documents already include the use of this concept. For example, in a preparatory document for the 1979 program, an evaluation of the new party's situation concludes that it lacks credentials as a "bearer of the working classes' will to hegemony" (Pedrosa, 1980: 88). Referring to the fundamental interest of workers and other subaltern sectors in constructing democracy, the document declares that "it is the space where the possibility of the hegemony of the classes comprising the PT can emerge and offer Brazilian society proposals for its transformation" (1980: 94).Thus, hegemony is conceived of as a "possibility" and democratic institutionality as the space for the development of this possibility. Subsequently, the concept would gain relevance as an expression of the party's strategy, the "logic" of political action.

The Fifth Conference defines an inflection point in the collective construction of the party's strategic ideas, the clearest declaration of the characteristic socialist aims of the PT's project and the outline of the path toward its construction. This conference acknowledged the fact that Brazilian society had been able to develop a dense civil society, the crucial site for the contest 
(PT, 1987: 13): "In civil society ...the bourgeoisie constructed reliable organizations ...that act not only to maintain its hegemony over the other classes but also to maintain its domination within the state apparatus. Conversely, the workers and middle classes also created organizations of civil society that allowed them to participate in the contest for hegemony and political power" (PT, 1987: 13).

The great organizational density of the popular sectors in civil society is complemented, according to this analysis, by the opening of spaces in the core of the political society of the state. Therefore, the document declares: "The Brazilian state, although greatly reinforced . . . is in no condition to close itself off completely from the subaltern classes' participation." Consequently, it concludes that the struggle for the growth of a popular democratic alternative presupposes action along three axes: organization of the party, organization of the popular movement, in particular of the workers organized in the Central Única de los Trabajadores (Unified Workers' Central—CUT), and occupation of institutional spaces through elections.

During the Sixth Conference of June 1989, which had as its primary objective the launching of Lula's candidacy for president and the preparation of the party's governmental program, the PT progressed in the characterization of the crisis that Brazilian society was experiencing. Defining it as a "global crisis" (one that had elements of "the development of a crisis of political hegemony") and a "structural" one ("not caused by momentary or circumstantial reasons") (PT, 1989: 5), the conference concluded that transcending it demanded "a strong and general shift of the correlation of forces in favor of the bourgeoisie or the proletariat," a struggle that would establish that "the level of political organization of the workers is sufficient for the beginning of a struggle for political hegemony. . . . The workers have constructed an instrument capable of challenging the hegemony of the bourgeois parties on a national level.... The PT has constructed an indisputable hegemony within the popular and workers' movement" (PT, 1989:5-6).

Here we see a change in the assessment of the state of the process of construction of hegemony from the "possibility of hegemony" expressed in the initial documents to the position that the party would fight for control of government through the presidential elections. Under these circumstances, the conference observed that the particular characteristics of this period had hindered "the clear formation of a hegemonic political and social bloc in the dominant camp" (PT, 1989: 8). To achieve an open and declared regime crisis, it would be necessary to "constitute a camp composed of antimonopolist, antilatifundium, and anti-imperialist forces within Brazilian society, forming the historical bloc that will serve as a bridge between the workers' most 
profound demands, stemming from their existing level of consciousness, and mobilization for the struggle for socialism" (1989: 7).

By the Seventh Conference, the party was enjoying increasing space within the state, especially after the national elections when it had had high hopes of a victory of Lula over Fernando Collor de Mello. The discussions focused on the relationship between the party and the rest of society both within the institutions and movements of civil society and with respect to the performance of PT-led administrations (PT, 1990: 36):

The relationship of the PT with Brazil's civil society is important because of the growing influence exercised in it. But this importance also stems from the fact that the workers' and other popular groups' struggle for hegemony and political power is occurring in a very radical form in the sphere of civil society. This situation is creating new conditions for the expansion and consolidation of democracy. It is occurring not only in the opposition between civil society and the state but also in the competition between the workers' social and economic organizations and the predominantly bourgeois entities, institutions, and conservative or reactionary employer associations that are designed to keep the popular sectors under the influence of bourgeois values.

The concept of hegemony is the leitmotif throughout the document, demonstrating that by the Seventh Conference it had assumed a relevant explanatory role in defining the PT's strategy: it would "struggle for hegemony on the road to constructing socialism" (PT, 1990: 37) and "considerably expand the PT's connection with civil society, allowing it to effectively question the existing ideological and political hegemony" (1990: 38). The party members were urged to "work for the PT's hegemony in society" (1990: 39) and seek to construct "a national project struggling for hegemony in society" (1990: 40). Therefore, the conference proposed "conquering provincial governments and electing a huge slate to the National Congress, transforming the correlation of forces in the country on an institutional level and thus creating a new reality for the social struggle and the contest for hegemony" (1990: 49).Correspondingly, the document calls for much more strategic precision in transforming city governments dominated by the PT into "instruments for questioning the hegemony in society" (1990: 57).

The holding of the First Congress would be an important moment in the collective discussion of the question of socialism and the strategy necessary to achieve it, producing a significant synthesis that continues in effect to this day. The Congress's resolutions characterized the strategy adopted as one "with an emphasis on the question of hegemony" (PT, 1991: 11). The critical role of this concept is clearly represented in the formulations of two fundamental sections of the resolutions entitled "The Central Role of the Struggle 
for Hegemony" and "The Contemporary Struggle for Hegemony." Although I cannot present all of the arguments, it is important to mention some central elements that structure the strategy in such a way as to include the function of the state and its relationship with the social movements of civil society. On the level of the state, the document (1991: 46) declares:

The PT's involvement in government should be seen as a decisive element in the construction of our hegemony, since it consists of governing, executing policies, and democratizing the state by having the popular classes participate in the control of government. It also means that the PT is coexisting and interacting with other social sectors, segments, and classes, thereby, in fact, exercising the right to hegemony, which is legitimated by the ballot box even if only on the municipal level.

At the same time, the following is added concerning the role of social movements in this struggle:

The accumulation of forces on the institutional front will not occur if we do not advance in the social sphere.... No governmental policy or parliamentary proposal is feasible without social support and public pressure, much less a national government. The growth, generalization, and politicization of social movements is fundamental to our policy of accumulation of forces and struggle for hegemony.

Therefore, in the resolutions of the First Congress political action for the construction of a new hegemony is conceived in the dual space of political society and civil society. The struggle for hegemony in that complex social space is described as follows (PT, 1991: 46-47):

The struggle for hegemony presupposes simultaneous action on ideological, political, and social levels. Within the institutions that we participate in, it includes working to expand the limits of participation, of democracy, of citizenship, and the strengthening of society vis-à-vis the state. It includes the diversity of social struggles carried on outside of the institutional structure, some of them "illegal." It incorporates the creation of organizational instruments through which the workers and Brazilian society can define the direction of the nation. It means a conflict of ideas, constructing a new culture, a new ethics, and a new social solidarity that opposes the dominant value structure. In summary, the struggle for hegemony today means the construction of the enormous social movement for reform in our country that is necessary for a viable alternative road for development whose principal characteristic is incorporating into full citizenship and work the millions of Brazilians who are marginalized and disinherited. 
These elements demonstrate the construction of a certain political logic for the definition of a party strategy based on the concept of "hegemony." From its secondary presence in the party's foundational documents of 19791980 through the more relevant use of the concepts of "civil society" and "subaltern classes" and the adoption of the concepts of "political and social bloc" and "historical bloc," and so forth, from the Fifth to the Seventh Conference to the appropriation of the concept as expressed in the First Congress's resolutions, the presence of Gramscian thought is an irrefutable reality.

\section{THE FARABUNDO MARTÍ NATIONAL LIBERATION FRONT}

Considering the case of the FMLN, we begin with an interesting account by Jorge Melendez, "Comandante Jonás," the principal military leader of the Ejército Revolucionario del Pueblo (People's Revolutionary Army-ERP) in Morazán, the headquarters of the party's armed contingent (interview, April 24, 1993; Burgos, 1993: 65):

In May or June of 1992, by the San Salvador volcano, we had a meeting of cadres in which one of the things we discussed was precisely Gramsci.Many of the compañeros said, "Yes, that's the direction we should take." It was the first time that I saw a discussion of theory in one of our meetings; that wasn't normal for us.From that point on, if not 100 percent, a good percentage of the ERP cadres would read works by Gramsci.

This is a curious episode in the Latin American country that gave birth to perhaps the most important guerrilla army in Latin American history, and because of this it deserves our attention.

We can distinguish three important stages in the process of creating an essentially unitary popular bloc in El Salvador and focus on three principal areas under discussion by the left: (1) The period from 1970 to 1980, from the creation of the first armed organization up to the formation of the FMLN. During this decade the most important discussion on the left was the question of armed struggle versus the peaceful road to revolution. (2) The period from 1981 to 1991, that of open civil war. During this phase the most important discussions in the FMLN concerned the character and meaning of the proposal for a negotiated end to the crisis. (3) The period from 1992 to the present, one of peace. In this final stage, the discussion has concerned the consequences of the peace accords and has included an intense debate on the meaning of "revolution," the conditions and characteristics of a revolutionary victory, and the nature of a suitable project under the new social configuration. Currently, the 
debate centers on how to develop the revolutionary process in a society in which the left presents itself as a rigorous guardian of the legitimacy of democratic institutions and methods.

During the first stage, the question of which road to revolution was resolved by revising the positions of the Partido Comunista Salvadoreño (Communist Party of El Salvador-PCS) in its Seventh Congress and its decision to undertake armed struggle by forming a unified military organization that would be accepted as the "vanguard" by a broad spectrum of popular organizations including the unions and a large part of the country's Catholic Church. Armed struggle against El Salvador's regime of terror was accepted as a necessity by the popular center and internationally legitimated.

During the second period the bases for a negotiated settlement of the conflict were formulated through the first proposals of the revolutionary government's program, the support provided by the 1981 Franco-Mexican Declaration, which recognized the Frente Democrático Revolucionario-FMLN as a belligerent force, the discussions within the FMLN concerning a negotiated settlement during the events of 1982, the 1984 rounds of dialogue held in La Palma and Ayagualo, the rounds held in the bishopric of El Salvador in 1987, the crisis originated by the FMLN offensive at the end of 1989, and the beginning of a dialogue in Geneva in April 1990. From this ten-year series of events, along with the war, which was obviously the principal issue, emerged proposals, discussions, and internal crises ${ }^{7}$ in which the new project appeared in embryo. These events culminated in the construction of the collective formulations contained in the Platform of the Democratic Revolution of September 1990, the first synthesis of the new ideas.

From that point on, a new period of reformulations with enormous consequences for the construction of a transformational project was born as the question of hegemony emerged. The concept most widely shared among all of the forces was that of "civil society," 8 as in "the supremacy of civil society" or "the hegemony of civil society." This orientation is present in the reading of the documents written by the different forces that made up the Front in that period and is a central idea in its most important collective documents. In the foundational documents of the new FMLN political party, this point is highlighted numerous times. For example, the preface to the "Principles" of the party states: "For 12 years the FMLN carried out a people's war in support of civil society to transcend militarism and open a new era for the Salvadoran nation" (FMLN, 1993: 16). And the fifth point is "Primacy of civil society. The FMLN supports the strengthening of civil society as the basis for democracy and for restraining the state's power over it; similarly, subordinating the military to civilian control in order to defeat militarism and consolidate the 
peace. We depart from the assumption that the will of civil society is the only legitimation of the authority of the state."

Other concepts pertaining to Gramsci's theory of hegemony that were used by the groups making up the FMLN are the concept of hegemony itself and that of the historical bloc. The concept of hegemony appears quite often in the writings of the Salvadoran left. Although its employment reflects a multiplicity of meanings, on the whole its usage approximates Gramsci's. The non-Gramscian use of the concept, viewing "hegemony" simply as "domination," was common in the 1970s. Thus, one spoke of the "hegemony of the oligarchy" or the "hegemony of the military over civil society" to designate coercion and domination. As the ideas of "the supremacy of civil society," "autonomy of social subjects," "self-management," "participatory democracy," and so forth, were combined with those of managing public affairs through social movements, new ideas of "revolution" and "revolutionary victory," and so forth, however, the concept of hegemony adjusted to the Gramscian tradition. According to Roberto Roca (Francisco Jovel), secretary general of the Partido Revolucionario de los Trabajadores Centroamericanos (Central American Workers' Revolutionary Party-PRTC) (interview, April 3, 1993; Burgos, 1993: 31),

Considering the Salvadoran reality, we stress the Gramscian thesis that the most desirable and viable hegemony in instituting an economic program is one that is arrived at by social consensus. If this is not achieved, there is no doubt that this hegemony will lead to dictatorship. This is why we are struggling for hegemony in El Salvador. In politics, it is nonsense to say that one is not looking for hegemony-we would be poor competitors; we are engaged in politics because we are trying to capture power. But what power? How would we exercise it? We want hegemonic power in order to pursue the possibility of achieving consensual acceptance for the exercise of that power. That is the most desirable hegemony, because it has the potential for transforming its programmatic proposals into reality. That is the challenge that we have here in El Salvador. Without a doubt, our ideas have much to do with Gramsci.

This approximation to the Gramscian concept of hegemony is also clear in a text by Joaquin Villalobos, principal leader of the Partido de la Revolución Salvadoreña-Ejército Revolucionario del Pueblo (Party of the Salvadoran Revolution-People's Revolutionary Army_PRS-EPR):

The negotiation accords have left civil society as the victor, allowing for the possibility of a real democracy in El Salvador. The struggle for hegemony through conquering the heart of civil society closes the door to the use of coercion. Instead, it opens a space for debate, democratic culture, and pragmatism as the most intelligent way of defending our principles and interests. 
Coercion must lose its force as the state is guided by civil society's permanently constructed consensus. Under these new conditions, any idea of a dictatorship, direct or indirect, for imposing solutions to problems is essentially antirevolutionary and negates the logic of the historical process. The new utopia is the construction of an environment where reason, not force, rules. In this environment, whoever has the best judgments, arguments, and democratic backing of the majority will have the potential to lead society without any imposition.

Another leader of the FMLN and secretary general of the Partido Resistencia Nacional (Party of National Resistance-RN), Fermán Cienfuegos (Eduardo Sánchez), utilized many of those concepts in Democratic Republic, a polemical text discussed in the Front during that period that anticipated the new theoretical developments (1986: 6-7).

The construction of the hegemony of the proletariat is developed in an open context of competition and debate between the distinct positions of the popular historical bloc. The political form of the revolutionary state, that is, the form that the revolution adopts in a postwar context, is that of a democratic republic.

Every party, that is, every manifestation of class and class alliances, should accept the challenge of constructing and reconstructing its hegemony permanently. within the heart of civil society.... Once elected to a state office, functionaries should represent the interests of the historical bloc in power and of the nation as a whole by detaching themselves from the most partisan interests of parties or groups. Alternating political power guarantees the renovation and revitalization of the process of representing the people's interests. Representative democracy will be enriched by participatory democracy and self-management.

Juan Ramón Medrano of the PRS-ERP, in turn, wrote in a 1992 essay, The FMLN's Fundamental Strategy for a New Nation:

As events developed we deepened our analysis and came to the realization that a negotiated political settlement was a new form of victory that would permit us to enter a new era from a balance of forces.

It also meant an increase in the conditions for improving the accumulation of forces in the search for political hegemony, which continues to be important for the construction of a unified power bloc of revolutionary forces.

In an exchange of ideas with me on the influence of Gramscian concepts on the FMLN's new orientation (interview, April 16, 1993; Burgos, 1993: 87), Medrano said, "The central concepts that we have borrowed from Gramsci fundamentally center on the historical moments of the role of the state, the system of political parties, and civil society. Utilizing these three 
aspects permits us to conceive of a more modern analysis of the totality of the Salvadoran socioeconomic structure."

These positions are those of the leaders of political parties that did not originate in the old Communist party and were therefore more flexible in their use of concepts and more open to theoretical and political innovation. During this period the other two parties of the FMLN, the PCS and its splinter group from the early 1970s, the Fuerzas Populares de Liberación (Popular Forces of Liberation-FPL), maintained a theoretical and political position much more strongly associated with the Leninist tradition. However, they not only shared and contributed to the shaping of the positions expressed in the FMLN's new project but also attempted to construct their own alternative view of it. Thus, we can find in these parties' documents elements that are indicative of the new political logic for thinking about the transformational process. One of the documents of the PCS's Eighth Congress (PCS, 1993: 810) states:

It is a transition from war to peace, from dictatorship to a democracy based on the hegemony of civil society and civil power.

The driving force of the democratic revolution proceeds from various sectors holding diverse ideologies. The convergence of all of these forces is the essence of this transition period, which is something that should be safeguarded. Seeking alliances, it follows that the search for consensus and agreement will be the principal method defining the relationships among these social forces.

Trying to find agreement opens up the possibility of transcending the driving forces of the democratic revolution. Experience has demonstrated that one can even reach agreement with those sectors traditionally associated with the opposition. Therefore, the construction of consensus in El Salvador has unsuspected possibilities.

In this and other documents we have the question of hegemony (sometimes expressed in earlier terms) and the use of the Gramscian concept proper in the form of "the hegemony of civil society."

At the same time, we can see the evaluation of this historical period and its consequences for the new project in the following document of the Central Committee of the FPL (1992: 44-45):

Reorganizing and acting from civil society. In this historical period, equality (social democracy) appears to depend more on the autonomous organization and self-management of civil society and the construction of political democracy than on the centralization of the state's power through a coup d'état or the taking of power through armed action of the left. Achieving the center of politi- 
cal and social decision making depends more on the progressive democratization of society and the state.

The same document adds the following in a footnote:

In the struggle for democracy one must transcend the bipolar view of "the state" and "the private sphere" that makes autonomous a dimension that at present is controlled by the state. "The public sphere" is a social space in which civil society can develop its collective life by decentralizing and extending the possibilities of participating in the fundamental decisions that affect the whole of society. It is in this space that socioeconomic reform can be linked with the political reform of the state. This is also the space in which society constructs the institutions of self-management that will displace the state and confine it to a progressively less powerful regulatory role. Opening up this dimension makes possible the self-management, co-partnership, and cooperativeness that creates between the private sphere and the state a space of socialization, decentralization, and autonomy for decision making.

Here we find the question of hegemony not only as it relates to civil society but also in its linkage to one of the most important Gramscian themes, the transition to the societal form that he calls "regulated society."

Besides Gramsci, a wealth of political and theoretical experience serves as a base for this new theorizing. Although it is clear that there were enormous differences among the FMLN forces that led to its organic and political division, there is no doubt that many of the principal elements of the new positions maintained by the parties composing the organization, either consciously or unconsciously as part of the "new common sense" that Aricó mentioned, are indebted to Gramsci's work. Therefore, it is not accidental that Gramsci appears in the analysis of the new political environment. In the words of the former Comandante Ana Guadalupe Martínez, it is about thinking of "a process of transformation that needed to be taken more slowly as a result of the international context. The process was much slower than many of us would have wanted, but it contained many more possibilities for a transformation in thought and culture that would be permanent, creating, in Gramsci's words, a hegemony of leftist ideas" (interview, April 30, 1993; Burgos, 1993: 74-75). ${ }^{9}$

\section{THE ARGENTINE COMMUNIST PARTY}

Finally, it is important to mention as an illustrative case some of the innovative elements in the political project of a party that was branded as one of 
the most dogmatic communist parties in Latin America, the Partido Comunista Argentino (Argentine Communist party-PCA).During its Sixteenth Congress in October 1986, it embarked on what it called a "revolutionary shift." For organizational and programmatic purposes, the party, purging itself of its past errors, sought a political and theoretical understanding more in tune with Argentine and Latin American reality.

Some of the intellectuals who contributed to the PCA's theorizing appropriated Gramsci, and, coincidentally, some interesting innovations appear in the Central Committee's November 29 and 30, 1996, report, published in a supplement to the magazine Nuestra Propuesta, a PCA weekly. On one hand, in this particular issue one encounters some interesting iconographic and representational elements that would surprise those who were familiar with the traditional ones employed even after the Sixteenth Congress. New faces appear-Mariátegui and Gramsci-and the report points to two directions for continuing the changes. For constructing a new "style" for the party's politics, it recommends recovering directions inspired by Marx, Guevara, the Cordoban labor leader Agustín Tosco, and Mariátegui. The first three were quite common after the Sixteenth Congress, but the fourth appears to be more recent. Furthermore, the report continues, "It is also necessary to re-create our political psychology, which was that of the manifest destiny of fatalistic optimism." In advocating this new "psychology," it recalls "Gramsci's belief that one must confront the difficult moments in the life of a revolutionary with the pessimism of the intellect and the optimism of the will" (PCA, 1996: 8). In summary, a new cadre of "models" is in evidence.

On the other hand, along with these modifications that I have called "iconographic" are conceptual elements that are a part of the comprehensive work of "renewing the core heritage" mentioned by Aricó:

1. A certain displacement of the idea of "ideology" by that of "culture" (PCA, 1996: 2):

Neoliberalism exercises its dominion fundamentally on the cultural level, attacking the constitutive values of popular identity, national identity, and the traditions of struggle contained in historical experience. ... If there is something that distinguishes this capitalism it is its cultural ideological force, especially in its battle against statist socialism and, beyond this, as cement for neoliberal domination over the people....It is a global and unified project of reproduction for capitalist expansion for the benefit of the most concentrated and powerful sectors, which find in this political, ideological, and cultural initiative the center of gravity for a complex system of doctrines and practices that absolutely monopolizes all aspects of social life. 
Proceeding from this analysis, the Central Committee's report exhorts its militants to "struggle on the cultural plane." This task defines what later on is mentioned as "a profound and vital struggle for transforming reactionary 'common sense' and installing a revolutionary socialist culture" (PCA, 1996: 4).

2. The replacement, in the revolutionary strategy adopted by this partywhich they call "constructing popular power" (a concept disseminated throughout Latin America as a result of the first Sandinista experience)—of the traditional revolutionary subject, "the working class," with "the people": "Understanding the transformations experienced by the social subject, the working class, permits us to equate the concept of the subject people with hegemony of the working class" (PCA, 1996: 5).

3 . The adoption of the concept of "autonomy" to designate the relationship between popular institutions and such political subjects. Proceeding from the idea of the "construction of new popular institutions with elements of autonomy and alternative culture" (PCA, 1996: 4), the report proposes a "program for the accumulation of forces founded on the effort to create bases of popular power" that permit "developing the unity of the revolutionary sec- tors that are acting in every part of the mass movement, developing common plans of resistance, and sharing paths that contribute to the emergence of the autonomy of the popular movement and its selforganization" (1996: 5).

4. The idea of the unity of the alternative social forces as a "bloc," as in "a popular bloc in conditions for creating and challenging power for the benefit of the people" or "[working toward] transforming those attacked by the model, who are vastly the popular masses, into a social-political bloc" (PCA, 1996: 3).

5. The proposal, with regard to the question of the political subject corresponding to the bloc working for change (PCA, 1996: 3), of a project

to defend, reproduce, and strengthen left culture, which is currently not only organically dispersed but also disaggregated and without deep roots in the social subject of the revolution ... a unity of the left that we conceive of as not just one of organizations but a unity of cultures of the left, which means unity of party members, of men and women, of organizations, of groups and currents, of traditions and approaches; of cultures.

Finally, while it is true that this new content seems to be simply "incrustations" on rocky material in which one can still glimpse the old ideas, often in clear inconsistency with the new, these new elements have a role in an evolution that is still an open question. 10 


\section{CONSEQUENCES OF THE SPILLOVER: AN EXPANSIVE RENEWAL OF PROJECTS}

The political practice of the left has always had a necessary relation to theoretical categories; for this reason, the type of category used cannot be a matter of indifference in determining what is constructed. The modification of concepts is therefore and always has been an important reality in the universe of socialist thought and of the political forces that correspond to it. The relevance of this point can be illustrated with two examples of experiments that utterly failed even though they occurred during the same historical period as experiments that succeeded.

At the beginning of the 1980s, after one of Bolivia's most combative periods, a left alliance controlled the central government under the presidency of Hernán Siles Suazo. A huge popular mobilization swept over Bolivia. The Central Obrera Boliviana (Bolivian Workers Central-COB) brought together all of the social organizations of the subaltern sectors: from students to neighborhood organizations, from miners' unions to housewives. The Federación Minera (Miners' Federation), along with the COB and the government, discussed and approved workers' self-management in the production of minerals and other state industries. Ultimately, a cadre of popular democracy involving social forces seldom seen in the rest of Latin America was created. In spite of this, a little later the left in government lost credibility and ceded ground - as a result of its own inefficiency and weakness, not because of the use of repression - to the neoliberal project, which rapidly gained hegemony that it retains to this day.

2. After the violent crisis of Alan García's government, the Peruvian left came to play an important role in the political arena through the project of the Izquierda Unida (United Left-IU). The left alliance won, among other seats, the Lima mayor's office (with the Alfonso Barrantes administration) and was preparing to challenge the central government. At the beginning of 1989, the IU held its First (and last) Congress, in which more than 3,000 delegates from all parts of the country participated, demonstrating an organized political force without precedent. The hullabaloo was, however, short lived. Before the presidential elections the left split, lost strength and prestige, and ceded its political space to an unknown political figure who had no direction, no political project, and no organized social base. Elected president, Alberto Fujimori adopted the neoliberal program, closed Congress, and consolidated his power with an alliance with the armed forces.

A common characteristic of these two experiences of the left was the complete lack of renewal of its political project, whose conceptual horizon 
remained prisoner to the old paradigms. Their political practices were also tied to the old disputes and dogmas, incapable of incorporating the new ferment and new experiences emerging from civil society. ${ }^{11}$

In the other direction, one can observe the continuation of important conceptual renewal in various Latin American experiments, although there are still inadequacies and limits. Programmatic points that 15 years ago were the political positions of alternative social movements and their theoreticians, unthinkable in parties of the left, are now part of their political projects, clearly demonstrating that the road from movement to party was the most creative and effective. It is no accident that in 1992 two works appeared that emphasized the necessity for a radical shift in leftist thought: Villalobos's Una revolución en la izquierda para una revolución democrática and the Brazilian Cristovão Buarque's A revolução na esquerda e a invenção do Brasil.The expression used here to convey the changes in concepts and practice necessary to left politics seems to me significant: "revolution."

In this continuing theoretical-political renewal there is a reordering of concepts in which "democracy," a subconcept in the previous paradigm (subordinated, for example, to the "dictatorship of the proletariat") and inferior to the category of "socialism" that submerged and extinguished it, becomes the articulating element of the entire transformation project. As content, the concept of democracy defines the ultimate strategic objective, socialist society, as the "radicalization of democracy" - a continuous and unlimited expansion and transcendence of bourgeois representative democracy through the various political practices of participatory democracy. Working within the confines of bourgeois representative democracy, one extends the spaces for acting in civil society and establishing a social democracy through the actions and involvement of the masses. Originating from the experience of the subaltern sectors, this process abandons the messianic form that the concept had for prior generations of leftists.

The new position of the concept of democracy as an instrument is expressed in the definition of the strategy as the "conquest of hegemony." The means of the transformation is thought of not as an assault on power but as a painstaking process of contesting hegemony through the construction of the socialist project within society and, simultaneously, creating "fractures" in the capitalist system. According to the PT's Program for Government, issued during the 1994 elections, "Since the end of the 1970s ... Brazil has been in the process of creating a new historical bloc of social and political forces," and the new subjects on the scene have altered the substance of democracy, "understood not only as the rule of law but also as a space for the expansion of new rights" (PT, 1994: 12).It is clear that a new idea of "democracy," one that 
is not only political but also economic and social, must arise as the content, the ideology, of the new historical bloc.

At the same time, that conceptual renewal includes a drastic reformulation of the hierarchical relationship between the party and social movements. There must be a rethinking of the idea of the central committee. It must cease to be seen as the driving force of the transformation through a revolutionary vanguard leading the masses toward revolution. Instead, social movements must have a primary place, become the rule, in the new projects. The party must take a back seat as an "articulator" and not as the illustrious, allpowerful vanguard, and this must be an articulation in which the autonomy of the popular movement and the political direction of the party do not correspond to an a priori formula but emerge from a relationship that is constructed, defined, and redefined by the daily struggle. In this redefinition, the "vanguard" is not a title of nobility for any party or group.

These experiments in conceptual renewal have spread through the exchange of experiences in the new spaces that have appeared in the past few years, an outstanding example of which is the San Pablo Forum. Aricó's "renewal of the core heritage" must be part of the shaping of the new universe of ideas emerging in Latin American revolutionary thought. It would be risky to predict the future, but what is undeniable is the significant role in the constitutive process of the Gramscian intervention.

\section{NOTES}

1. I do not know whether the conference proceedings were published. Coutinho and Nogueira (1988) included some of the papers, and some were published in La Ciudad Futura (August 1987, suppl. 4).

2. In 1950 Lautaro published Letters from Prison, in 1958 Historical Materialism and the Philosophy of Benedetto Croce (with a preface by Héctor Agosti), in 1960 The Intellectuals and the Organization of Culture, in 1961 Literature and National Life (translated by José Aricó with a preface by Agosti), and in 1962 Machiavelli, Politics, and the Modern State (translated and with a preface by Aricó). The two remaining volumes, based on the sixvolume edition of the Italian publisher Einaudi, were published in Spanish much later: the Mexican Juan Pablos Editor published Past and Present in 1977 and The Risorgimento in 1980.

3. Historical Materialism and the Philosophy of Benedetto Croce and Letters from Prison both appeared in 1966 and Machiavelli, Politics, and the Modern State, Literature and National Life, and The Intellectuals and the Organization of Culture in 1968.

4. This observation is pertinent for Brazil, Mexico, Peru, and Venezuela but not for Chile, Argentina, and Uruguay, where military dictatorships have subjected university life to relentless censorship.

5. For example, the important theoretical work by Orlando Nuñez. 
6. It should be kept in mind that in 1988 the Partido dos Trabalhadores (Workers' party - PT) held 36 mayoralties and more than 1,000 town council seats, among them the São Paulo mayor's office, held by Luiza Erundina. Furthermore, in 1990 it had 35 federal deputies and 93 provincial deputies. In 2001 the PT was represented by 3 state governors, 187 mayors ( 7 of them of state capitals, including the City of São Paulo), 7 senators, 59 federal deputies, 90 state deputies, and 2,485 town council members.

7. Some of these critical moments-for example, the assassination of Mélida Anaya Montes ("Ana María") and the subsequent suicide of Salvador Cayetano Carpip ("Marcial")—are detailed in Castañeda's (1993) La utopia desarmada.

8. On the use of this concept, Ernesto Cisneros, the former representative of the Frente Farabundo Martí de Liberación Nacional (Farabundo Martí Front for National LiberationFMLN) in Brazil, said, "What is interesting, for example, is the discussion surrounding 'civil society,' which is something very new in El Salvador. It is striking how that idea resonated. Everyone speaks about 'civil society' now” (interview, June 1993).

9. In 2001 the FMLN had 31 federal deputies (of a total of 84) and controlled 54 municipios in 13 departments (of a total of 262 in 14 departments), among these the capital, San Salvador.

10. It is symptomatic of this direction that the web site of the school for cadres of the Partido Comunista Argentino (Aergentine Communist party) (http://www.geocities.com/ escuelapca/) includes the faces and messages of Antonio Gramsci and José Carlos Mariátegui.One might also mention the experimental university known as the Cátedra Libre Antonio Gramsci (http:// www.geocities.com/catedragramsci/) and the recently established Asociación Gramsci Internacional, Sección Argentina, affiliated with the International Gramsci Society. For a detailed study of the history of Gramsci's ideas in Argentina, see Burgos (1999).

11. It is impossible within the limits of this article to discuss these hypotheses in connection with the two experiments mentioned. They are based in both cases on participant observation, which allowed me to see at first hand how a hard-won political patrimony was squandered.It is interesting to note, in this regard, the lack of sufficient critical reflection on the part of well- known analysts of the left (e.g., Harnecker, 2000).

\title{
REFERENCES
}

\author{
Aricó, José \\ 1985 "Prologue," in Julio Labastida Martín del Campo (ed.), Hegemonia y \\ alternativas políticas en América Latina. Mexico City: Siglo XXI. \\ 1988 La cola del diablo. Buenos Aires: Puntosur. \\ Buarque, Cristovão \\ 1992 A revolução na esquerda e a invenção do Brasil. Rio de Janeiro: Paz e \\ Terra. \\ Burgos, Raúl \\ 1993 "El Salvador: los desafíos de la Revolución Democrática (Reportaje al FMLN \\ a un año de la firma de los acuerdos de paz)." Análisis 5(4). \\ 1999 "Os Gramscianos argentinos: cultura e política na experiência de Pasado y \\ Presente." Ph.D. dissertation, State University of Campinas. \\ Castañeda, Jorge \\ 1993 La utopia desarmada. Buenos Aires: Ariel. \\ Cienfuegos, Fermán \\ 1986 La república democrática. Managua: Roque Dalton.
}


Córdova, Arnaldo

1988 "Antonio Gramsci e a esquerda mexicana," in Carlos Nelson Coutinho and Marco Aurélio Nogueira (eds.), Gramsci e a América Latina. São Paulo: Paz e Terra.

Coutinho, Carlos Nelson 1989 "Cidadão brasileiro." Teoria \& Debate 9.

Coutinho, Carlos Nelson and Marco Aurílio Nogueira (eds.) 1987 Gramsci em América Latina. Rio de Janeiro: Paz e Terra.

FMLN (Frente Farabundo Martí de Liberación Nacional) 1993 Documentos politicos. San Salvador: Alternativa.

FPL (Fuerzas Populares de Liberación) 1992 Estrategia para el desarrollo socio-económico y la democracia en El Salvador. San Salvador.

Harnecker, Marta 2000 Tornar possível o impossível: A esquerda no limiar do século XXI. São Paulo: Paz e Terra.

Labastida Martín del Campo, Julio (ed.) 1985 Hegemonia y alternativas políticas en América Latina. Mexico City: Siglo XXI. Medrano, Juan Ramón 1992 Estrategia integral del FMLN para un nuevo pais. San Salvador: n.p.

PCA (Partido Comunista de la Argentina) 1996 "Informe del Comite Central realizado los dias 29 y 30 de noviembre." Nuestra Propuesta, December 12.

PCS (Partido Comunista Salvadoreño) 1993 Resoluções del 8 Congreso: Sobre la transición, formas de lucha, las alianzas y la unidad. San Salvador.

Pedrosa, Maria 1980 Sobre o PT. São Paulo: Ched Editorial.

Portantiero, Juan Carlos 1991 "Entrevista." El Ojo Mocho (Buenos Aires) 4 (Summer).

PT (Partido dos Trabalhadores)

1987 Resoluções políticas do 5 Encontro. n.p.

1989 Resoluções políticas do 6 Encontro. São Paulo: Diretório Nacional. 1990 Resoluções do Sétimo Encontro Nacional do PT. São Paulo: Comissão Executiva Nacional do PT.

1991 Resoluções do Primeiro Congresso do PT. São Paulo: Diretório Nacional. 1994 Programa de gobierno. São Paulo: PT.

Villalobos, Joaquin 1992 "Una revolución en la izquierda para una revolución democrática.” MS, San Salvador. 1993 Paper presented at the conference "Reconciliación en tiempos de transición," San Sal- vador. 